\title{
PROSTYTUCJA I JEJ NOWE FORMY ORAZ ZJAWISKA POKREWNE A REGULACJE PRAWNE
}

\begin{abstract}
Streszczenie. Publikacja ma na celu przedstawienie zjawiska prostytucji i form jej podobnych. W artykule zostały przedstawione różne sposoby definiowania terminu prostytucja, autorka opisała również inne zjawiska, które przybierają postać nierządu, wraz z ich uwarunkowaniami. Opisane zostały konkretne przepisy prawa karnego, a także akty międzynarodowe, które problematykę prostytucji regulują wprost. W podsumowaniu autorka rozważa kwestie uregulowań prawnych dotyczących prostytucji oraz jej rozwoju.

Slowa kluczowe: prostytucja, sponsoring, prostytucja nieletnich, inne zjawiska związane z prostytucją, regulacje prawne, aspekt międzynarodowy.
\end{abstract}

\section{UWAGI WSTEPNE}

Prostytucja jest zjawiskiem powszechnie istniejącym, rzeczywistością społeczną, która przybiera niejedno „imię”. Nieustanne zainteresowanie świadczeniem i korzystaniem z usług prostytucji w ostatnich latach wykształciło jej nowe formy. Prostytucja bowiem, jako zjawisko dynamiczne, elastyczne, dostosowuje się do istniejących realiów. Istnieje we wszystkich kulturach, warstwach społecznych, nie wyłączając tej najwyższej. Obecnie, przy daleko posuniętej swobodzie seksualnej, jej obraz zmienia się wraz z rozwojem czynników społecznych, ekonomicznych, a nawet prawnych.

\section{POJECIE PROSTYTUCJI}

W literaturze naukowej istnieje wiele najrozmaitszych definicji pojęcia prostytucji, jednakże na potrzeby tematu ograniczę się tylko do kilku z nich. Sam termin prostytucja pochodzi z łacińskiego prostitutio, oznaczającego 'nierząd uprawiany w celu osiągnięcia zysku'. Niektórzy wywodzą ten termin od łacińskiego prostare, co oznacza 'stać przed czymś', 'wystawiać, ofiarować się na sprzedaż' (Imieliński 1990, 9; Kowalczyk-Jamnicka 1998, 177). Pierwsze próby zdefiniowania zjawiska zostały podjęte przez Solona, który twierdził, iż każda osoba

\footnotetext{
*Szpital Uniwersytecki w Krakowie (Dział Obsługi Prawnej), ppaulina101@gmail.com.
} 
oddająca swoje ciało do dyspozycji za pieniądze zajmuje się prostytucją (za Pospiszyl 2008, 224). Ulpian zaś za prostytutkę uważał kobietę oddającą się jawnie większej liczbie mężczyzn dla osiągnięcia zysku (za Sztobryn-Giercukiewicz 2004, 13). Socjolog Iwan Bloch natomiast wyróżnił prostytucję jako formę pozamałżeńskich stosunków seksualnych odznaczających się tym, że prostytuująca się osoba oddaje się wielu osobom jawnie, notorycznie, najczęściej za opłatą, w formie zawodowego sprzedawania się (za Jasińska 1967, 225). Z kolei socjolog Wilhelm Brensdorf pojęcie prostytucji rozumie jako świadczenie usług seksualnych „okolicznościowo lub zawodowo w zamian za korzyści materialne”, bez wyboru lub z wyborem ograniczonym, z wykluczeniem aspektu uczuciowego, w jakiejkolwiek formie, przy częstej zmianie partnerów (Brensdorf 1976, 201). Zbliżone rozumienie terminu prostytucja proponuje Magdalena Jasińska. Jej zdaniem ,prostytutka jest osobą, która zaspokaja potrzeby seksualne przygodnych partnerów za zapłatę, bez zaangażowania uczuciowego, i w zasadzie bez wyboru" (Jasińska 1976, 437). Charles H. McCaghy opisuje prostytucję jako zachowanie o znaczeniu seksualnym, w którym występuje uczuciowa obojętność i element transakcji - zapłaty, przy czym zachowanie obu stron zmierza wyłącznie do wymiany usług (za Kowalczyk-Jamnicka 1994, 147; Pospiszyl 2008, 225). Zbigniew Lew-Starowicz rozumie prostytucję jako różnorodne kontakty hetero- czy homoseksualne, uprawiane w celach zarobkowych. Stosunek seksualny traktowany jest w kategoriach rzeczowych i wyklucza więź emocjonalną (Lew-Starowicz 1986, 70). Kolejną definicję proponuje Kazimierz Imieliński, według którego prostytucja cechuje się oddawaniem własnego ciała do dyspozycji większej liczby osób w celu osiągnięcia przez nie zadowolenia seksualnego i pobieraniem za to wynagrodzenia materialnego (Imieliński 1990, 14).

Jak widać, etymologia słowa ,prostytucja” sprawia, że kojarzy się ona nierozerwalnie z oddawaniem własnego ciała w zamian za korzyści materialne. W podanych definicjach eksponowane są najczęściej trzy kluczowe jej elementy, tj. świadczenie usług seksualnych, otrzymywana w zamian ekonomiczna gratyfikacja oraz brak zaangażowania emocjonalnego (Antoniszyn, Marek 1985, 9-11). Wskazać tu można także na tak zwaną triadę: prostytutka, klient i usługa seksualna.

\section{SPONSORING}

Współcześnie seks stał się towarem, który można sprzedać, a komercjalizacja usług seksualnych w ostatnich latach przeobraża rynek prostytucji. Od kilku lat obserwujemy, jak rozwijają się nowe formy zarabiania ciałem: sponsoring seksualny, e-prostytucja czy prostytucja wirtualna.

Sponsoring seksualny powszechnie kojarzony jest ze współczesną, ekskluzywną i wyrafinowaną formą prostytucji, postrzeganą głównie jako związki zawarte między osobą sponsorowaną a sponsorem (Gardian-Miałkowska 2012, 
292). Sam termin sponsoring wywodzi się z nauk ekonomicznych i oznacza finansowe lub rzeczowe wspieranie różnych dziedzin życia dla osiągnięcia własnych celów marketingowych czy komunikacyjnych. Istota tych działań sprowadza się do uzyskania korzyści przez wszystkich uczestników umowy (Mruk 2002, 146). Omawiając sponsoring seksualny, można wskazać, że zawiera on pewne elementy charakterystyczne dla wyżej wymienionych cech sponsoringu marketingowego, jest bowiem specyficzną umową zawartą między sponsorem a osobą sponsorowaną, opartą na zapłacie w zamian za uzyskanie usług seksualnych. Związek taki zwykle opiera się na jasnych i konkretnych zasadach. Jako najczęstsze motywy wchodzenia w relacje sponsorskie podaje się chęć spełnienia określonych potrzeb finansowych, podniesienie standardu życia i szybkiego zysku (Gardian 2007, 51). Renata Gardian-Miałkowska w swoich pracach wskazuje, że sponsoring może przybrać jedną z trzech form zapłaty: finansową, rzeczową lub usługową. Pierwsza $\mathrm{z}$ wymienionych następuje w formie pieniężnej, kojarzona jako wynagrodzenie za spełnienie usługi, może również przybrać formę np. płatności czesnego za studia. Drugi sposób polega na otrzymaniu przedmiotów, korzyści materialnych w postaci prezentów, np. telefonu, perfum itp. Trzecia forma zapłaty obejmuje pokrycie kosztów wyjazdów weekendowych czy wakacyjnych. W zależności od układu zapłata może przybrać postać nawet trzech form naraz (Gardian-Miałkowska 2012, 298). Autorka ta wskazuje również, że w praktyce sponsoring może być: jednorazowy, okresowy lub stały (tamże).

Internet niewątpliwie ułatwia zainteresowanym wejście na taką drogę prostytucji. Sieć stała się miejscem rozpowszechniania anonsów towarzyskich i seksualnych, co stworzyło większą możliwość korzystania z usług prostytucji, która pod taką postacią jest łatwiejsza niż w formie świadczenia płatnych usług seksualnych w agencjach towarzyskich. Analiza ogłoszeń osób szukających sponsora lub chcących uzyskać korzyści ze sprzedaży własnego ciała pozwala przypuszczać, iż popularność tego zjawiska jest duża. Osobę chcącą zarobić na sprzedaży swojego ciała łatwo można znaleźć wśród ofert zamieszczanych w towarzyskich portalach internetowych. Oferta może przybrać różną formę: tekstu, zdjęć czy też filmików, a osobie korzystającej z takiego sposobu zdobywania „klientów” Internet daje większą swobodę wyboru oraz ustalenia warunków (Kitlińska 2005, 11). Osoba sponsorowana, bo tak przyjmuje się ją nazywać, sama decyduje, z kim będzie się spotykać, na jakich zasadach, za ile, ustalając częstotliwość spotkań oraz preferencje seksualne. Warto tu podkreślić, że zjawisko to dotyczy zarówno kobiet, jak i mężczyzn, młodzieży licealnej, osób pracujących zawodowo, a nawet osób w dojrzałym wieku (Gardian-Miałkowska 2012, 298 i n.). Na jednym z portali internetowych „roksa.pl”, oferty zazwyczaj zawierają zdjęcia, w zdecydowanej większości z zasłoniętą twarzą,

${ }^{1}$ Darmowy serwis internetowy, zawierający ogłoszenia towarzyskie i anonse erotyczne. Aby wejść do serwisu, wystarczy zaznaczyć opcję „wchodzę”. 
jednakże ukazujące inne walory ciała. Osoba zamieszczająca ogłoszenie podaje wiek, wymiary - tzn. wagę i wzrost, proponowany zakres usług, godziny pracy, stawkę oraz umiejętności posługiwania się językami obcymi. Stawka za godzinę waha się od 120 do 500 zł, a za noc od 1200 do nawet 5000 zł. Ceny różnią się w zależności od regionu i miasta.

Porównując cechy prostytucji i sponsoringu, można spostrzec, że ich definicje wzajemnie się uzupełniają i powielają. Motywacją w obu przypadkach jest osiągnięcie korzyści majątkowej, chociaż tu mogą pojawić się pewne wątpliwości co do formy, w jakiej ma zostać przyjęta. W przypadku sponsoringu osoba sponsorowana ma możliwość wyboru partnera i teoretycznie nie występuje tu ich większa liczba (Kotowska 2009, 241). Biorąc pod uwagę powyższe, sponsoring można przyjąć za szczególną formę prostytucji.

\section{ZJAWISKO PROSTYTUCJI NIELETNICH}

Omawiając zjawisko prostytucji i sponsoringu, nie można pominąć zjawiska nierządu nieletnich, którzy dobrowolnie podejmują aktywność seksualną, często nie zdając sobie sprawy z konsekwencji prawnych ich czynów (Kilińska-Pękacz 2015, 82).

W przeciwieństwie do prostytucji osób dorosłych polskie prawo karne (ustawa z dnia 6 czerwca 1997 r. - Kodeks karny, Dz.U. z 1997 r. Nr 88, poz. 553 ze zm.; dalej: k.k.) zakłada penalizację osób korzystających z usług nieletnich. Mowa tu o art. $200 \S 1$ k.k., dotyczącym m.in. odbywania stosunku seksualnego z małoletnim poniżej 15 lat, jak również art. 199 § k.k., dotyczącym nadużycia zależności lub uwiedzenia małoletniego. Wyznaczenie granicy wieku, która obejmuje szczególną ochroną małoletnich poniżej lat 15 przed wszelkimi formami aktywności seksualnej, wynika z przeświadczenia braku dojrzałości psychicznej takich osób, zwłaszcza gdy chodzi o rozpoczęcie życia seksualnego (Bojarski 2012, 544). Ustalona granica wynika z przyjętego przez ustawodawcę założenia, że osoba $\mathrm{w}$ tym wieku nie jest w stanie podjąć prawnie relewantnej decyzji, mającej walor społeczny i prawny, rozpoznając wszelkie jej realia i następstwa, w konsekwencji przyzwalając na podjęcie z nią określonych czynności seksualnych (Krajewski 2010, 7).

W ostatnich latach dość powszechna i popularna stała się prostytucja nieletnich, funkcjonująca w slangu młodzieżowym pod nazwami galerianki czy świnki, oznaczającymi osobę poniżej 18. roku życia, szukającą w centrum handlowym sponsora fundującego jej jakiś przedmiot (Kilińska-Pękacz 2015, 89). Jednakże nie jest to jedyny sposób prostytuowania się nieletnich, obszarem aktywności młodzieży w sferze seksualnej jest już nie tylko świat realny, ale także, coraz częściej, wirtualny, w którym młodzi ludzie nawiązują różne kontakty (Krajewski 2010, 6). Zjawisko prostytucji nieletnich rozszerza się, a z upływem czasu przybiera 
różne formy ${ }^{2}$. Często młodzi ludzie sami ogłaszają się w Internecie, poszukując sponsora.

Galerianki świadczą odpłatne usługi seksualne, zaspokajając potrzeby klientów przy braku uczuć, w zamian za korzyści materialne, dlatego też ich działanie stanowi formę prostytucji (Kilińska-Pękacz 2013, 39). Ustawodawca, chcąc uchronić małoletnich przed odpłatną formą aktywności seksualnej, wprowadził pojęcie nierządu jako jednego z przejawów demoralizacji (art. 4 $\S 1$ ustawy z dnia 26 października $1982 \mathrm{r}$. o postępowaniu w sprawach nieletnich, Dz.U. z 1982 r. Nr 35, poz. 228 ze zm.). Demoralizacja jest wynikiem, a zarazem przejawem nieprzystosowania społecznego nieletniego, jednak aby jego zachowanie zostało uznane za demoralizujące, musi się powtarzać i utrzymywać przez pewien czas. Jednorazowa próba „bycia prostytutką” nie powinna stanowić podstaw do zastosowania wobec nieletniego środka przewidzianego w ustawie (Kudrelek 2009, 112).

W art. $199 \S 3$ k.k. ustawodawca dążył również do wygrania walki z prostytucją nieletnich, albowiem osoba, która obcuje płciowo z małoletnim lub dopuszcza się wobec takiej osoby innej czynności seksualnej albo doprowadza ją do poddania się takim czynnościom albo do ich wykonania, nadużywając zaufania lub udzielając w zamian korzyści majątkowej, lub osobistej albo jej obietnicy, podlega karze. W literaturze można się spotkać ze zdaniem, że regulacja art. 199 $\S 3$ k.k. jest nadmierną i nieuzasadnioną penalizacją życia seksualnego małoletnich (Bielski 2013, 758-759), ponieważ, zwiększając zakres penalizacji związanych ze sferą seksualności małoletnich, nie dostrzega się sytuacji poniesienia odpowiedzialności karnej za doprowadzenie małoletniej poniżej lat 18 do obcowania płciowego w zamian za korzyść majątkową na podstawie art. 199 § 3 k.k. przez np. siedemnastolatka. Postuluje się, aby wprowadzono dodatkowe znamię czynów zabronionych o charakterze seksualnym, godzących w dobro małoletniego, a mianowicie zróżnicowanie wieku między sprawcą a pokrzywdzonym (Kilińska-Pękacz 2015, 90).

Artykuł $200 \S 1$ k.k. stanowi o odpowiedzialności karnej za obcowanie płciowe $\mathrm{z}$ małoletnim poniżej lat 15, a także za dopuszczenie się wobec takiej osoby innej czynności seksualnej, za doprowadzanie jej do poddania się takim czynnościom albo do ich wykonania. Przedmiotem ochrony jest tu wolność seksualna małoletniego, rozumiana jako wolność od ingerowania w sferę życia seksualnego (Krajewski 2010, 6 i n.). Dla bytu przestępstwa wskazanego w art. $200 \S 1$ k.k. nie ma znaczenia wyrażenie zgody przez małoletniego na relację seksualną. Nie jest tu istotne, z czyjej inicjatywy nastąpiła czynność seksualna, czy wyszła ona ze strony małoletniego, czy nie. Co do zasady dla bytu przestępstwa znaczenie ma obcowanie płciowe lub inna czynność seksualna podjęta z osobą poniżej 15. roku

${ }^{2}$ Przykładowo można wskazać tu prostytucję wymuszoną, do której dzieci nakłaniane są przez domowników, prostytucję dworcową często uprawianą przez dzieci na tzw. gigancie. 
życia, a karalność polega na samym odbyciu z małoletnim czynów seksualnych. Istotne jest tu też niedopuszczenie do demoralizacji seksualno-obyczajowej małoletniego (Budyn-Kulik i in. 2010, 413).

\section{INNE ZJAWISKA}

Poza tradycyjnymi formami pojawiają się także nowe, niespecyficzne, które nie zawsze spełniają kryterium charakterystyczne dla „klasycznej” prostytucji. Jako że prostytucja zawsze kojarzyła się z bezpośrednim kontaktem klienta i prostytutki, należałoby się zastanowić, czy można mówić o prostytucji w przypadku, gdy mamy do czynienia z przeniesieniem tych relacji w obszar wirtualny. Upowszechnienie Internetu spowodowało pojawienie się tak zwanej prostytucji wirtualnej. Do najpopularniejszych form tego rodzaju prostytucji zaliczyć można między innymi sex chat, czyli interaktywną rozmowę za pomocą kamery internetowej (Kowalczyk-Jamnicka 2013, 77). Praca ta polega na pokazywaniu swoich wdzięków za pośrednictwem kamery wideo i na jak najdłuższym utrzymaniu zainteresowania klienta, który płaci za czas połączenia. Osoba posiadająca konto w określonym serwisie internetowym po zalogowaniu ma możliwość wyboru odpowiedniej kandydatki lub kandydata i obejrzenia transmisji na żywo. Dodatkowym atutem korzystania z takiej formy przyjemności jest możliwość podjęcia rozmowy na czacie. Wpisując w komunikator czatu określone życzenia, klient może spowodować, iż wybrana osoba rozbierze się, zatańczy, położy na łóżku (Kowalczyk-Jamnicka 2013, 77).

W związku z prostytucją wirtualną pozostaje także do rozważenia kwestia seks telefonu czy seks SMS-ów. Moda ta przywędrowała do polski pod koniec lat dziewięćdziesiątych z krajów Europy Zachodniej i Stanów Zjednoczonych, gdzie kobiety uwodzicielskim głosem kusiły klientów, utrzymując jak najdłuższy czas połączenia telefonicznego, za które płacił klient (tamże, 78). Seks telefon możemy uznać za miękką postać prostytucji, ponieważ osoba korzystająca $\mathrm{z}$ takiego sposobu zaspokajania swoich potrzeb seksualnych nie widzi tej, z którą rozmawia lub, jak w przypadku seks SMS-ów, piszącej. Pracować w tej branży mogą osoby w każdym wieku, bo ani wiek, ani wygląd nie ma znaczenia, jedynie umiejętność utrzymania jak najdłużej zainteresowania rozmówcy. Tego typu firmy wykupują reklamę w popularnych pismach czy telegazecie, umieszczając tam erotyczne ogłoszenia, które zazwyczaj opatrzone są zdjęciami półnagich, albo nagich, atrakcyjnych kobiet czy, coraz częściej, mężczyzn. Do zdjęcia z reguły dołączony jest opis typu: „Witaj, masz ochotę się zabawić? Wyślij SMS...”. Koszt takiego połączenia lub wiadomości może być różny, w zależności od ustalonej stawki. 


\section{REGULACJE PRAWNE}

Dominujące w Europie regulacje prawne dotyczące prostytucji oparte są na założeniach modelu abolicjonistycznego, który nie penalizuje prostytucji jako takiej, tylko wszystkie przestępstwa okołoprostytucyjne. Model ten odrzuca represję i reglamentację, zakładając, że podejmowane działania prawne powinny być skierowane przeciwko prostytucji, a nie prostytutkom. Polska, podpisując międzynarodową Konwencję ONZ z 1949 r. w sprawie zwalczania handlu ludźmi i eksploatacji prostytucji, opowiedziała się za systemem abolicyjnym, dlatego też polskie prawodawstwo, opierając się na założeniach tegoż systemu, nie penalizuje samej prostytucji, ale wszystkie przestępstwa okołoprostytucyjne, tj. sutenerstwo, stręczycielstwo, kuplerstwo i handel ludźmi.

W obecnie obowiązującym kodeksie karnym zmuszanie do prostytucji jest zabronione, ponieważ zgodnie z art. 203 k.k.: „kto przemocą, groźbą bezprawną, podstępem lub wykorzystując stosunek zależności lub krytyczne położenie, doprowadza inną osobę do uprawiania prostytucji, podlega karze pozbawienia wolności od roku do lat 10". Przepis ten stanowi pewnego rodzaju novum w odniesieniu do poprzednich regulacji karnych, w których nie znajduje swojego odpowiednika (Kowalewska-Łukuć 2017, 8).

Jako przedmiot ochrony przestępstwa, polegającego na zmuszaniu innej osoby do prostytucji, wskazuje się wolność seksualną (Warylewski 2016, 927), jak również godność osoby doprowadzanej do uprawiania prostytucji (Błońska 2006, 57). Stroną przedmiotową w tym przypadku będzie sprawca, który doprowadza inną osobę do uprawiania prostytucji z użyciem przemocy, groźby bezprawnej, podstępu lub z wykorzystaniem stosunku zależności, lub krytycznego położenia. Podmiotem przestępstwa zmuszania do prostytucji co do zasady może być każdy, ponieważ jest to przestępstwo powszechne. Wyjątkiem będzie zmuszanie do prostytucji poprzez wykorzystanie stosunku zależności, przez co, w tym przypadku przestępstwo z art. 203 k.k., będzie przestępstwem indywidualnym (Warylewski 2016, 934). Czynu w takiej postaci może dopuścić się jedynie sprawca, od którego osoba pokrzywdzona pozostaje rzeczywiście w pewien sposób uzależniona (tamże). Skutkiem znamienia czynnościowego przestępstwa z art. 203 k.k. jest podjęcie się przez osobę pokrzywdzoną uprawiania prostytucji. Nie chodzi tu tylko o doprowadzenie osoby do uprawiania prostytucji i zmuszanie jej do rozpoczęcia nierządu. Przepis ten obejmuje także przypadki polegające na zmuszaniu do kontynuowania prostytucji uprawianej uprzednio (Kowalewska-Łukuć 2017, 11). Zachowanie się sprawcy ukierunkowane jest na osiągnięcie celu w postaci doprowadzenia ofiary do uprawiania prostytucji, dlatego też przestępstwo zmuszania do tego procederu jest czynem umyślnym, bezpośrednim, o czym świadczy katalog środków zawarty w art. 203 k.k. (Warylewski 2016, 935). 
Kolejną regulacją kodeksową, odnoszącą się do prostytucji, jest art. 204 k.k. zawierający regulacje takich przestępstw okołoprostytucyjnych jak stręczycielstwo, kuplerstwo, sutenerstwo. Przestępstwo stręczycielstwa zostało uregulowane w art. 204 § 1 k.k., który wskazuje, że kto nakłania inną osobę do uprawiania prostytucji podlega karze pozbawienia wolności od 3 miesięcy do lat 5 . Warto w tym miejscu zwrócić uwagę na fakt, iż obecne uregulowania przestępstwa stręczycielstwa różnią się od poprzednich, ponieważ znamiona stręczycielstwa uregulowanego w kodeksie karnym z 1969 r. wyczerpywało nakłanianie innej osoby do uprawiania nierządu, a w obecnym uregulowaniu karalne jest jedynie nakłanianie podjęte w celu osiągnięcia korzyści majątkowej (Kowalewska-Łukuć 2017, 12). Przedmiotem ochrony przestępstwa stręczycielstwa jest obyczajność (Bielski 2013, 857), a także godność ludzka (Błońska 2006, 51 i n.). Stronę przedmiotową przestępstwa stręczycielstwa wyczerpuje nakłanianie innej osoby do uprawiania prostytucji, przy czym nakłanianie to musi nastąpić w celu osiągnięcia korzyści majątkowej. Znamię czynnościowe, polegające na nakłanianiu do uprawiania prostytucji, jest przykładem podżegania do czynu karalnego. Celem przestępstwa stręczycielstwa jest osiągnięcie korzyści majątkowej, przez co sprawca dopuścić się go może w zamiarze bezpośrednim i wyłącznie umyślnie. Podmiotem co do zasady może być każdy, ponieważ jest to powszechny typ czynu zabronionego (Kowalewska-Łukuć 2017, 13 i n).

Kuplerstwo jest drugim z przestępstw okołoprostytucyjnych wymienionych obok stręczycielstwa, uregulowanym w art. 204 § 1 k.k. Znamiona przestępstwa kuplerstwa, a także sankcje, przedmiot oraz strona przedmiotowa, są analogiczne jak w przypadku stręczycielstwa (tamże, 14). W przypadku kuplerstwa wskazuje się, że znamię czynnościowe obejmuje zachowania zarówno czynne, jak i bierne, dlatego nie ma przeszkód, by dopuścić możliwość odpowiedzialności za przestępstwo kuplerstwa przez zaniechanie (Pohl 2015, 861). Przestępstwa kuplerstwa dopuścić się można wyłącznie umyślnie i to jedynie w zamiarze bezpośrednim, a jego sprawcą może być każdy, ponieważ jest to powszechny typ czynu zabronionego. Cel osiągnięcia korzyści majątkowej odnosi się zarówno do nakłaniania do uprawiania prostytucji, jak i ułatwiania jej uprawiania (Kowalewska-Łukuć 2017, 16).

Trzecim przestępstwem okołoprostytucyjnym, stypizowanym w art. 204 $\S 2$ k.k., jest sutenerstwo. Zgodnie z tym przepisem, kto czerpie korzyści majątkowe $z$ uprawiania prostytucji przez inną osobę podlega karze pozbawienia wolności od 3 miesięcy do lat 5. Przedmiotem ochrony przestępstwa sutenerstwa jest, jak w poprzednich przypadkach, obyczajność w sferze życia seksualnego oraz godność ludzka. Znamię czynnościowe przestępstwa sutenerstwa realizuje się w czerpaniu korzyści majątkowej z uprawiania prostytucji przez inną osobę. Użyte sformułowanie „czerpie” stypizowane zostało jako przestępstwo wieloczynowe. Aby mówić o dokonaniu czynu z art. 204 § 2 k.k., sprawca musi zatem uzyskać korzyść majątkową z cudzej prostytucji co najmniej dwukrotnie. Dla realizacji 
znamion sutenerstwa wystarczające będzie także uzyskanie korzyści majątkowej z prostytucji co najmniej dwóch osób, chociażby było jednorazowe (Pohl 2015, 862). Istotą działania sprawcy jest osiągnięcie korzyści majątkowej, a nie tylko cel jej osiągnięcia. Dlatego też przestępstwo sutenerstwa zostaje dokonane dopiero z chwilą osiągnięcia przez sprawcę przynajmniej dwukrotnie korzyści majątkowej $z$ uprawiania prostytucji przez inną osobę. Potencjalnym podmiotem sutenerstwa może być każdy, ponieważ jest to powszechny typ czynu zabronionego. W praktyce jednak sprawcą będzie osoba, która dopuści się umyślnie, w zamiarze bezpośrednim i ewentualnym, przestępstwa sutenerstwa w postaci czerpania zysków (tamże, 866).

W tym miejscu należy zwrócić uwagę na fakt posłużenia się przez ustawodawcę powtarzającym się terminem „uprawianie prostytucji”, sformułowanym we wszystkich wyżej wymienionych przepisach, co zdaje się przesądzać o konieczności powtarzalnego charakteru prostytuowania się osoby pokrzywdzonej, jako powtarzalne świadczenie innym osobom usług seksualnych w zamian za ekonomiczne korzyści (Bielski 2013, 851).

Rozważając regulacje karne znajdujące się w polskim systemie prawnym, warto wspomnieć o przepisach kodeksu wykroczeń, w rozdziale dotyczącym wykroczeń przeciwko obyczajności publicznej - mowa tu o art. 141 i 142 ustawy z dnia 20 maja 1971 r. - Kodeks wykroczeń (tekst jedn. Dz.U. z 1971 r. Nr 12, poz. 114 ze zm.; dalej: k.w.).

Zgodnie $\mathrm{z}$ art. 142 k.w., kto natarczywie, narzucając się, lub w inny naruszający porządek publiczny sposób proponuje innej osobie dokonanie z nią czynu nierządnego, mając na celu uzyskanie korzyści materialnej, podlega karze aresztu, ograniczenia wolności albo grzywny. W przepisie tym zostało stypizowane wykroczenie polegające na proponowaniu czynu nierządnego, traktowanego jako propozycja odpłatnego świadczenia usługi seksualnej (Kulesza 2016, 931). Przedmiotem ochrony jest tu obyczajność publiczna, wskazuje się również na poboczny przedmiot ochrony, którym jest wolność jednostki (tamże). Czynnością sprawczą jest proponowanie w określony sposób innej osobie czynu nierządnego, tj. złożenie przedmiotowej propozycji, która powinna być natarczywa, narzucająca się lub w inny sposób naruszająca porządek publiczny. Wykroczenia z tego przepisu można dopuścić się jedynie w drodze działania, ponieważ chodzi tu o głośne nakłanianie, nagabywanie, chwytanie za ubrania i ciągnięcie, używanie wulgarnych słów i gestów (tamże, 932). Wykroczenie z art. 142 k.w. zostało uregulowane jako czyn umyślny, ograniczony jedynie do zamiaru bezpośredniego sprawcy. Propozycja składana przez sprawcę ma dotyczyć czynu nierządnego, przez co należy rozumieć odpłatne świadczenie usługi seksualnej (tamże, 933).

Art. 141 k.w. natomiast mówi o tym, że kto w miejscu publicznym umieszcza nieprzyzwoite ogłoszenie, napis lub rysunek albo używa słów nieprzyzwoitych, podlega karze ograniczenia wolności, grzywny do 1500 złotych albo karze nagany. Przedmiotem ochrony w wyżej wymienionym przepisie jest 
obyczajność, inaczej moralność i porządek publiczny. Strona przedmiotowa tego wykroczenia polega na tym, że sprawca umieszcza nieprzyzwoite ogłoszenie, działając w miejscu publicznym. Warto tu wskazać, czym jest miejsce publiczne. W literaturze podaje się, iż jest to miejsce dostępne dla nieograniczonej liczby osób, jednakże „miejsce publiczne” nie jest tożsame z terminem „publicznie” (Zbrojewska 2013, 649).

\section{ASPEKT MIĘDZYNARODOWY}

Aktami prawa międzynarodowego, które regulują problematykę prostytucji, są: Konwencja ONZ w sprawie zwalczania handlu ludźmi i eksploatacji prostytucji ${ }^{3}$ oraz Konwencja ONZ w sprawie likwidacji wszelkich form dyskryminacji kobiet ${ }^{4}$. Pierwsza z nich nakłada na państwa, które ją podpisały, określone zobowiązania, mające na celu ograniczenie wykorzystywania osób do świadczenia usług seksualnych. We wstępie do przedmiotowej konwencji wskazano, że prostytucja i towarzyszące jej zło - handel ludźmi w celach prostytucji, są sprzeczne z godnością i wartością człowieka oraz zagrażają dobru jednostki, rodziny i społeczeństwa. Artykuł 1 konwencji zakłada w ustawodawstwie państw ratyfikujących penalizację czynów, polegających na dostarczaniu, zwabianiu lub uprowadzaniu w celach prostytucji innej osoby, nawet za jej zgodą, oraz czynów, polegających na eksploatacji prostytucji innej osoby, nawet za jej zgodą. Artykuł 2 zaś przewiduje penalizację utrzymywania lub prowadzenia bądź świadomego finansowania domu publicznego, jak również udział w jego finansowaniu. Zgodnie z tym przepisem penalizacja ma obejmować także świadome wynajmowanie komuś lub odnajmowanie od kogoś budynku bądź innych pomieszczeń dla celów prostytucji innych osób. Każda ze stron niniejszej konwencji zgadza się zastosować wszelkie niezbędne środki w celu cofnięcia lub uchylenia jakiegokolwiek istniejącego prawa, zarządzenia lub przepisu administracyjnego, w myśl którego osoby zajmujące się lub podejrzane o zajmowanie się prostytucją podlegają specjalnej rejestracji

\footnotetext{
${ }^{3}$ Konwencja w sprawie zwalczania handlu ludźmi i eksploatacji prostytucji (Convention for the Suppression of the Traffic in Persons and of the Exploitation of the Prostitution of Others) - przyjęta przez Zgromadzenie Ogólne ONZ rezolucją nr 317 (IV) z 2 grudnia 1949 roku, otwarta do podpisania 21 marca 1950 w Lake Success w stanie Nowy Jork, weszła w życie 25 lipca 1951 roku zgodnie z art. 24. Ratyfikowana przez Polskę na podstawie ustawy z 29 lutego $1952 \mathrm{r}$. (Dz.U. Nr 13, poz. 78). Plik dostępny online: http://www.kcik.pl/doc/konw-w-spr-zwalcz-handlu-ludz-i-eksploat-prostyt_1952.pdf [dostęp 30.03.2018].

${ }^{4}$ Konwencja w sprawie likwidacji wszelkich form dyskryminacji kobiet (Convention on the Elimination of All Forms of Discrimination against Women, CEDAW) - uchwalona rezolucją nr 34/180 Zgromadzenia Ogólnego ONZ z dnia 18 grudnia 1979 roku, która weszła w życie 3 września 1981 roku. Ratyfikowana przez Polskę w 1980 r. Plik dostępny online: https://amnesty.org.pl/wp-content/uploads/2016/04/Konwencja-Likwidacja-dyskryminacji-kobiet.pdf [dostęp 30.03.2018].
} 
bądź też obowiązane są posiadać specjalny dokument, bądź wreszcie powinny podporządkować się wyjątkowym wymaganiom co do nadzoru lub zgłaszania.

Druga z wymienionych konwencji, tj. w sprawie likwidacji wszelkich form dyskryminacji kobiet, w artykule 6 wskazuje, że „Państwa Strony podejmą wszelkie stosowne kroki, w tym również ustawodawcze, w celu położenia kresu wszelkim formom handlu kobietami oraz ciągnięciu zysków z prostytucji kobiet". Konwencja nie narzuca państwom wprost określonego podejścia, które powinny przyjąć w celu walki z handlem kobietami i wykorzystywaniem ich do prostytucji. Jeśli chodzi o wykorzystywanie kobiet do prostytucji można wyróżnić dwie sytuacje. Pierwsza, gdy kobiety są przymuszane do prostytucji i świadczą usługi seksualne wbrew swojej woli, a zyski z ich nierządu trafiają do innych osób. Druga występuje, gdy kobiety nie są zmuszane do świadczenia usług seksualnych, ale ich praca pozostaje pod kontrolą i służy czerpaniu zysków (Więckiewicz 2013, 250).

\section{PODSUMOWANIE}

Uwspółcześniony nierząd przestaje być zjawiskiem kryminalnym, a jego ramy coraz częściej wykraczają poza regulacje kodeksowe. Wbrew powszechnemu mniemaniu współczesna prostytucja nie jest już zjawiskiem z marginesu społecznego, zajmują się nią ludzie pochodzący z rożnych warstw społecznych, posiadający różny poziom wykształcenia i status ekonomiczny. Zjawisko prostytucji nieustannie wymusza na społeczeństwie potrzebę jej regulowania i dostosowywania się do istniejących realiów. Granica pomiędzy tym, co jest prostytucją a tym, co jeszcze nią nie jest, zależy od podejścia i interpretacji zjawiska. Liberalizacja życia i daleko posunięta swoboda seksualna powodują coraz częstsze problemy z uchwyceniem i rozgraniczeniem pojęcia prostytucji. Przemiany, jakie zachodzą w obrębie tego zjawiska, powodują ciągłą aktualizację sposobów podchodzenia do tematu nierządu, począwszy od systemu prohibicji, polegającym na zakazie uprawiania prostytucji pod groźbą kary, przez reglamentacyjny, poprzez kontrolę prostytucji, rejestrowanie prostytutek i poddawanie każdej z nich przymusowym oględzinom lekarskim, po system abolicjonistyczny, polegający na zniesieniu wszelkiej rejestracji prostytutek, a zarazem dekryminalizacji uprawiania nierządu i karania osób czerpiących zyski z usług prostytucji (Warylewski 2016, 921). Prostytucja jest zjawiskiem powszechnie istniejącym, dlatego też warto zastanowić się, czy aktualne regulacje prawne w sposób właściwy i kompleksowy odnoszą się do tego zjawiska oraz czy prawo powinno ingerować w dobrowolność seksualną człowieka. Prostytucja funkcjonuje niejako poza kontrolą państwa, płatne usługi seksualne są tematem trudnym do określenia i znalezienia wiarygodnych danych na temat osób trudniących się tym procederem.

Polskie prawo nie zabrania prostytucji, osoby prostytuujące się nie są piętnowane, a prostytucja jako taka nie jest karalna, co nie oznacza, że jest legalna. 
Uprawiając seks za pieniądze, nie możemy zostać pociągnięci do odpowiedzialności karnej, a osoba, która sama uprawia nierząd, nie może zostać ukarana, to znaczy nie grożą jej żadne konsekwencje prawne związane z uprawianiem prostytucji. Oczywiście inaczej sprawa wygląda w sytuacji korzystających z usług prostytucji nieletnich, gdzie prawo penalizuje sprawców dopuszczających się czynności seksualnej z osobą małoletnią.

Polski system prawny, opierając się na założeniach sytemu abolicyjnego, odstępuje i jednocześnie nie ingeruje w świat prostytucji jako takiej, a jedynie ją zwalcza i odpowiednio reaguje na wykorzystywanie osób do prostytucji i czerpanie z niej zysków, co wynika z przekonania o tym, że kobiety są zmuszane do usług seksualnych. Rzeczywistość jest jednak inna, czasami kobiety podejmują dobrowolnie taką pracę, z własnego wyboru, często same próbują znaleźć przygodnych partnerów seksualnych przez Internet, szukając możliwości zarobkowania. Również międzynarodowe regulacje prawne opierają się na założeniu minimalnego standardu ochrony osób świadczących usługi seksualne w postaci nałożenia obowiązku karania sprawców, wykorzystujących cudzą prostytucję. Tak samo w Polsce - karalne jest sutenerstwo, stręczycielstwo, kuplerstwo i zmuszanie do prostytucji, jakby prawodawca nie zauważał innych aspektów związanych z tym zjawiskiem.

Warto tu nadmienić, że poza świadczeniem tradycyjnych usług seksualnych dochodzą także usługi towarzyskie, jak w przypadku sponsoringu, który coraz częściej rozumiany jest jako inna forma prostytucji, inaczej mówiąc - prostytucja „w lepszym opakowaniu”.

Kwestie sponsoringu czy umieszczania anonsów towarzyskich z propozycjami sprzedaży usług seksualnych w żaden sposób nie są uregulowane wprost. Przepisy prawne pomimo regulacji kodeksu wykroczeń, które poniekąd mogłyby posłużyć zwalczaniu tego procederu, tym samym ograniczeniu kupna seksu, w praktyce nie spełniają swojej roli. Przykładowo art. 142 k.w. wskazuje na ochronę obyczajności i porządku publicznego, ale przepis ten nie jest skierowany bezpośrednio do osób uprawiających prostytucję, tylko zabrania takich jej przejawów, które zakłócają jednocześnie porządek publiczny. W konsekwencji czego prostytucja, w tym przypadku, może stanowić wykroczenie określone tylko w wyjątkowych sytuacjach, wymienionych w art. 142 k.w.

Tak samo art. 141 k.w. - biorąc pod uwagę zawarty tam zwrot „miejsce publiczne i umieszczenie nieprzyzwoitego ogłoszenia”, teoretycznie mógłby posłużyć jako przepis zwalczający sprzedaż seksu przez Internet, jednakże problem, który mógłby się tu pojawić, to kwestia językowej definicji miejsca. Zgodnie z orzecznictwem działanie „W miejscu publicznym” musi być podjęte w przestrzeni dostępnej dla ogółu, do której nieograniczony dostęp ma bliżej nieokreślona liczba ludzi, chociażby w chwili zachowania sprawcy nikt poza nim samym tam się nie znajdował (wyr. Trybunału Konstytucyjnego z dnia 21 września 2015 r., sygn. K 28/13). Czy zgodnie z tym za przestrzeń publiczną, rozumianą w sposób 
abstrakcyjny, moglibyśmy uznać portal społecznościowy lub towarzyski, niejako miejsce dostępne dla nieograniczonej liczby osób? Z drugiej strony, czy nadmierna ingerencja prawna $\mathrm{w}$ dobrowolność seksualną nie naruszałaby podstawowych praw człowieka? Każdy bowiem ma prawo do życia, wolności i bezpieczeństwa swej osoby ${ }^{5}$. Człowiek powinien podejmować niezależne decyzje dotyczące własnego życia seksualnego, a seksualność jako integralna część osobowości każdej istoty powinna dawać prawo do swobodnych kontaktów.

Warto w tym miejscu również zwrócić uwagę na fakt, że prostytucja czy też sponsoring opiera się na pewnego rodzaju umowie ustnej, zawartej pomiędzy dwiema osobami oczekującymi korzyści, seksualnych lub materialnych. Niestety, umowa zawarta w taki sposób nie ma doniosłości prawnej, ponieważ świadczenie usług seksualnych jest sprzeczne z zasadami współżycia społecznego, a przez to, w świetle kodeksu cywilnego, jest czynnością nieważną.

Reasumując, aktualne regulacje prawne dotyczące prostytucji nie są wystarczające dla zapobieżenia jej rozwojowi, a zarazem przestępczości związanej z jej uprawianiem. Prostytucja i wszystkie aspekty z nią związane działają poza obszarem prawa. Kryminalizacja przestępstw jest ostatecznością, co oznacza, że dokonana jest wtedy, gdy inne środki okazują się niewystarczające. Inaczej mówiąc, posługujemy się przepisami prawa karnego wówczas, gdy wobec określonego społecznie szkodliwego zachowania inne sposoby jego zwalczenia są bezradne.

Warto byłoby zastanowić się nad legalizacją takiego sposobu zarabiania, uznaniem świadczenia usług seksualnych za oficjalny zawód i jego opodatkowaniem. Legalizacja to przecież nie tylko niekryminalizowanie, to także wprowadzenie przepisów, które uregulowałyby świat usług seksualnych, poruszających takie chociażby kwestie jak: monitorowanie tej strefy poprzez rejestrację i regulacje podatkowe, składki zdrowotne, wymogi sanitarne, zdrowotne, a nawet wsparcie psychologiczne. Przykładem regulacji jest system niemiecki, w którym kobiety mają obowiązek rejestracji swojej działalności, rozliczania się i przechodzenia badań kontrolnych.

\section{BIBLIOGRAFIA}

Antoniszyn Michał, Andrzej Marek. 1985. Prostytucja w świetle badań kryminologicznych. Warszawa: Wydanie Prawnicze.

Bielski, Marek. 2013. „Rozdział XX k.k. Przestępstwa przeciwko wolności seksualnej i obyczajności”. W Kodeks karny. Część szczególna. T. 2: Komentarz do art. 117-277 k.k. Red. Andrzej Zoll. 1641. Warszawa: Wolters Kluwer.

${ }^{5}$ Zgodnie z art. 3 Powszechnej Deklaracji Praw Człowieka (rezolucja Zgromadzenia Ogólnego ONZ 217 A (III) przyjęta i proklamowana w dniu 10 grudnia 1948 r.). Plik dostępny online: http://www.unesco.pl/fileadmin/user_upload/pdf/Powszechna_Deklaracja_Praw_Czlowieka.pdf [dostęp 30.03.2018]. 
Błońska, Barbara. 2006. „Zagadnienie przedmiotu ochrony prawnokarnej w przypadku przestępstw eksploatacji prostytucji”. Studia Iuridica 46: 37-60.

Bojarski, Marek. 2012. Prawo karne materialne. Część ogólna i szczególna. Warszawa: Wolters Kluwers.

Brensdorf, Wilhelm. 1976. „Socjologia prostytucji”. W Seksuologia. Red. Hans Giese. 200-201. Warszawa: Państwowy Zakład Wydawnictw Lekarskich.

Budyn-Kulik, Magdalena, Patrycja Kozłowska-Kalisz, Marek Kulik, Marek Mozgawa. 2010. Kodeks karny. Praktyczny komentarz. Red. Marek Gozdawa. Warszawa: Wolters Kluwer.

Gardian, Renata. 2007. Zjawisko sponsoringu jako forma prostytucji kobiecej. Kraków: Oficyna Wydawnicza Impuls.

Gardian-Miałkowska, Renata. 2012. „Sponsorowana prostytucja w środowisku akademickim”. Prace Instytutu Profilaktyki Społecznej i Resocjalizacji 20: 291-304.

Imieliński, Kazimierz. 1990. Manowce seksu - prostytucja. Łódź: Res Polona.

Janikowski, Jarosław. 2017. „Wykroczenie proponowania czynu nierządnego”. Prokuratura i Prawo 4: 108-123.

Jasińska, Magdalena. 1967. Proces społecznego wykolejenia młodocianych dziewcząt. Warszawa: Wydawnictwo Prawnicze.

Kilińska-Pękacz, Agnieszka. 2013. „Prawne aspekty zjawiska galerianek”. Problemy Opiekuńczo-Wychowawcze 1 (3): 38-42.

Kilińska-Pękacz, Agnieszka. 2015. „Prawo karne wobec dobrowolnej aktywności seksualnej małoletnich”. Studia z Zakresu Prawa, Administracji i Zarzadzania 7: 81-92.

Kotowska, Monika. 2009. „«Sponsoring» - forma prostytucji czy patologii społecznej? Próba oceny zjawiska”. Biatostockie Studia Prawnicze 6: 239-249.

Kowalczyk-Jamnicka, Małgorzata. 1994. „Wybrane zagadnienia etologii prostytucji”. W Patologia spoleczna w strukturze przeobrażeń ustrojowych Polski. Materiaty Ogólnopolskiej Konferencji zorganizowanej przez Katedrę Pedagogiki Specjalnej w Bydgoszczy w dniach 25-26 maja 1993 roku. Red. Eugeniusz Bielecki, Teresa Sołtysiak. 147-158. Bydgoszcz: Wyższa Szkoła Pedagogiczna.

Kowalczyk-Jamnicka, Małgorzata. 1998. „Charakterystyka współczesnej prostytucji”. W Problemy wspótczesnej patologii społecznej. Red. Bronisław Urban. 177-182. Kraków: Wydawnictwo Uniwersytetu Jagiellońskiego.

Kowalczyk-Jamnicka, Małgorzata. 1998. Społeczno-kulturowe uwarunkowania prostytucji w Polsce. Bydgoszcz: Wydawnictwo Uczelniane Wyższa Szkoła Pedagogiczna.

Kowalewska-Łukuć, Magdalena. 2017. Prostytucja i czerpanie z niej korzyści majątkowych - analiza prawno-porównawcza. Warszawa: Instytut Wymiaru Sprawiedliwości.

Krajewski, Radosław. 2012. „Prawnokarne aspekty dobrowolności seksualnej małoletnich”. Prokuratura i Prawo 10: 5-26.

Kudrelek, Jan. 2009. Postępowanie szczególne w procesie karnym. Postępowanie w sprawach nieletnich. Szczytno: Wyższa Szkoła Policji w Szczytnie.

Kulesza, Jan. 2016. „Rozdział XVI. Wykroczenia przeciwko obyczajności publicznej”. W Kodeks wykroczeń. Komentarz. Red. Paweł Daniluk. 913-915. Warszawa: Wydawnictwo C.H. Beck.

Lew-Starowicz, Zbigniew. 1986. Stownik seksuologiczny. Warszawa: Agencja Omnipress.

Mruk, Henryk. 2002. Komunikowanie się w biznesie. Poznań: Wydawnictwo Akademii Ekonomicznej w Poznaniu.

Pohl, Łukasz. 2015. Prawo karne. Wykład części ogólnej. Warszawa: Wolters Kluwer.

Pospiszyl, Irena. 2008. Patologie społeczne. Warszawa: Wydawnictwo Naukowe PWN.

Powszechna Deklaracja Praw Człowieka. http://www.unesco.pl/fileadmin/user_upload/pdf/Powszechna_Deklaracja_Praw_Czlowieka.pdf [dostęp 30.03.2018].

Sztobryn-Giercuszkiewicz, Joanna. 2004. Psychologiczne aspekty prostytucji. Łódź: Dajas. 
Warylewski, Jarosław. 2016. „Prostytucja (art. 203 i 204 KK)”. W System Prawa Karnego. T. 10: Przestepstwa przeciwko dobrom indywidualnym. Red. Jarosław Warylewski. 921. Warszawa: Wydawnictwo C.H. Beck.

Więckiewicz, Karolina. 2013. „Polskie prawo karne wobec zjawiska prostytucji w świetle międzynarodowych standardów praw człowieka - wybrane aspekty". W Prostytucja Studium Zjawiska. Red. Robert Kowalczyk. 250-253. Kraków: Krakowska Akademia im. Andrzeja Frycza Modrzewskiego.

Zbrojewska, Monika. 2013. „Komentarz do art. 141”, „Komentarz do art. 142”. W Grzegorczyk Tomasz, Wojciech Jankowski, Monika Zbrojewska. Kodeks wykroczeń. Komentarz. Red. Tomasz Grzegorczyk. 649-650. Warszawa: Wolters Kluwer.

\title{
Orzecznictwo
}

Wyrok TK z dnia 21 września 2015 r., sygn. K 28/13.

\begin{abstract}
Akty prawne
Konwencja w sprawie zwalczania handlu ludźmi i eksploatacji prostytucji (ratyfikowana na podstawie ustawy z dnia 29 lutego 1952 r. - Dz.U. Nr 13, poz. 78) (Dz.U. Nr 41, poz. 278). http://www. kcik.pl/doc/konw-w-spr-zwalcz-handlu-ludz-i-eksploat-prostyt_1952.pdf [dostęp 30.03.2018].

Konwencja w sprawie likwidacji wszelkich form dyskryminacji kobiet przyjęta przez Zgromadzenie Ogólne Narodów Zjednoczonych dnia 18 grudnia 1979 r. (Dz.U. z 1982 r. Nr 10, poz. 71). https://amnesty.org.pl/wp-content/uploads/2016/04/Konwencja-Likwidacja-dyskryminacji-kobiet.pdf [dostęp 30.03.2018].

Ustawa z dnia 20 maja 1971 r. - Kodeks wykroczeń (Dz.U. z 1971 r. Nr 12, poz. 114).

Ustawa z dnia 6 czerwca 1997 r. - Kodeks karny (Dz.U. z 1997 r. Nr 88, poz. 553 ze zm.).
\end{abstract}

\section{Paulina Szota}

\section{PROSTITUTION AND ITS NEW FORMS AND RELATED PHENOMENA AGAINST LEGAL PROVISIONS}

\begin{abstract}
The publication aims at presenting the phenomenon of prostitution and its forms. The article presents different ways of defining the term of prostitution. The author also described other phenomena and conditions of their development, which take the form of prostitution. The article describes specific provisions of criminal law as well as of international acts that regulate prostitution directly. In summary, the author tried to consider the issues of legal regulations regarding prostitution and its development.
\end{abstract}

Keywords: prostitution, sponsoring, prostitution of minors, other phenomena related to prostitution, legal regulations, international aspect. 